Revision of Nomenclature of the Upper Part of the Green River Formation, Piceance Creek Basin, Colorado, and Eastern Uinta Basin, Utah

GEOLOGICAL SURVEY BULLETIN 1394-G 


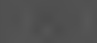

(1)

$+1$ 
Revision of Nomenclature of the Upper Part of the Green River Formation, Piceance Creek Basin, Colorado, and Eastern Uinta Basin, Utah

By W. B. CASHION and JOHN R. DONNELL

\section{CONTRIBUTIONS TO STRATIGRAPHY}

GEOLOGICA L S UR VEY B ULLETIN $1394-$ G

Nomenclature changes involving the Evacuation Creek and Parachute Creek Members of the Green River Formation and the Uinta and Bridger Formations

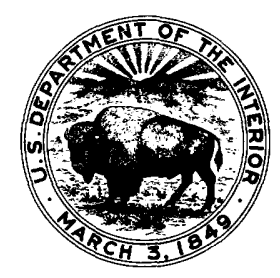


UNITED STATES DEPARTMENT OF THE INTERIOR

ROGERS C. B. MORTON, Secretary

GEOLOGICAL SURVEY

V. E. McKelvey, Director

Library of Congress catalog-card No. 74-600018

For sale by the Superintendent of Documents, U. S. Government Printing Office Washington, D. C. 20402 - Price 25 cents (paper cover)

Stock Number 2401-02473 


\section{CONTENTS}

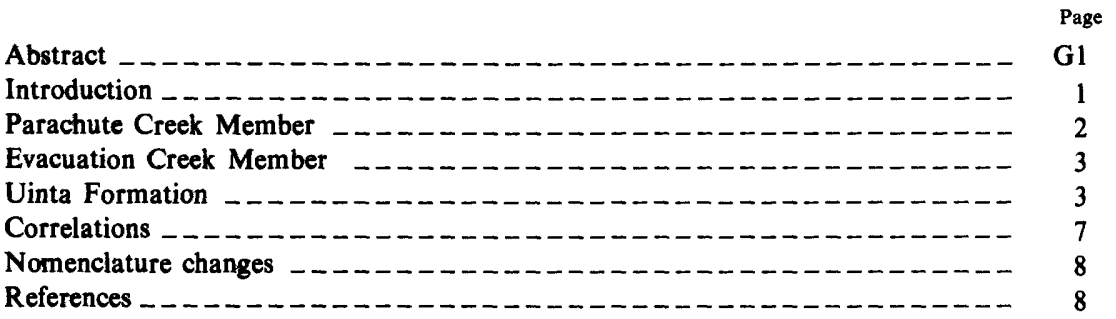

\section{ILLUSTRATIONS}

Page

FIGURE 1. Map showing locations of core holes and measured sections _..__ _- G2

2. Stratigraphic sections of the upper part of the Green River Formation --

3. Diagram showing stratigraphic nomenclature of Bradley (1931) and of this paper

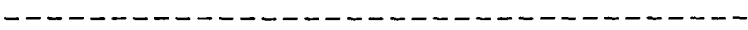

\section{TABLE}

TABLE 1. Locations of core holes and sections shown in figure 1 



\title{
REVISION OF NOMENCLATURE OF THE UPPER PART OF THE GREEN RIVER FORMATION, PICEANCE CREEK BASIN, COLORADO, AND EASTERN UINTA BASIN, UTAH
}

\author{
By W. B. Cashion and John R. Donnell
}

\begin{abstract}
Stratigraphic study of the upper part of the Green River Formation and overlying beds in northwestern Colorado and northeastern Utah shows that the upper part of the Parachute Creek Member at the type locality in the Piceance Creek basin, Colorado, is the same lithologic and stratigraphic unit as the Evacuation Creek Member at its type locality in the Uinta Basin. The Evacuation Creek Member as used by most workers in the Piceance Creek basin is equivalent to the lower part of the Unita Formation in the Uinta Basin. The name Evacuation Creek Member is abandoned and is replaced by the Parachute Creek Member in the eastern Uinta Basin and by the Uinta Formation in the Piceance Creek basin.
\end{abstract}

\section{INTRODUCTION}

The Green River Formation (Eocene) in Colorado and Utah has been studied by numerous workers investigating the geology and resources of oil shale and saline minerals of the formation. Although much has been learned in recent years of the stratigraphy of the formation, little has been done to update the stratigraphic nomenclature in Colorado and Utah since a classic paper by Bradley (1931) established member names in the Piceance Creek basin and in the eastern Uinta Basin more than 40 years ago. Changes in nomenclature are needed for the best presentation of the results of current studies and for facilitating future studies. Many workers have become very comfortable with the old names and have made mental adjustments for the awkward nomenclature, but such adjustments are not an acceptable permanent solution.

Bradley (1931) first divided the Green River Formation of the Piceance Creek basin and eastern Uinta Basin (fig. 1) into four members, named, in ascending order, the Douglas Creek, Garden Gulch, Parachute Creek, and Evacuation Creek Members. Changes adopted in this paper involve the Parachute Creek and Evacuation Creek Members (fig. 2). 


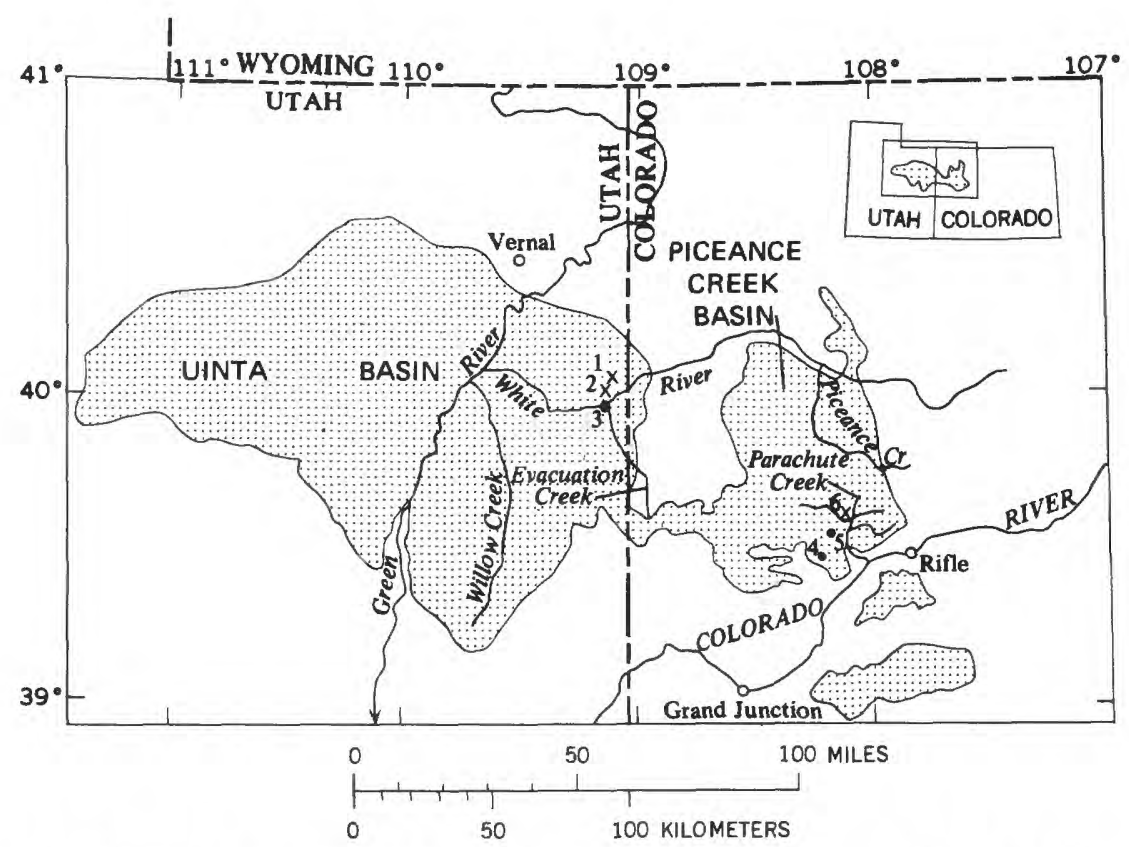

FIGURE 1. - Locations of core holes (dots) and measured sections (X). Green River Formation is patterned.

\section{PARACHUTE CREEK MEMBER}

The type locality of the Parachute Creek Member is along Parachute Creek in Garfield County, Colo. The member was named by Bradley (1931, p. 11), who stated that it is distinguished from other parts of the Green River Formation by its content of oil-shale beds, including all the large groups of rich beds, most of the individual rich beds, and a very large proportion of the low-grade oil shale. In this member the richest and thickest sequence of oil-shale beds exposed in the Piceance Creek and Uinta Basins is extremely persistent and is called the Mahogany ledge on the outcrop and the Mahogany zone in the subsurface. That part of the member that includes the Mahogany ledge and the section above it consists mostly of oil shale with some marlstone and is more than 730 feet thick along Parachute Creek. That part of the member below the Mahogany ledge consists dominantly of barren marlstone with minor amounts of rich oil shale and is 560 feet thick. About 15 miles northwest of the type locality, near the depositional center of the Piceance Creek basin, the Mahogany zone is thicker and richer than at the type locality, and the upper part of the member thins to 500 feet. In contrast, that part below the Mahogany zone thickens to about 1,000 feet and consists dominantly of rich oil shale and large amounts of nahcolite $\left(\mathrm{NaHCO}_{3}\right)$. In the Piceance Creek basin and the eastern part of the Uinta Basin numerous thin tuff beds are interspersed through the upper part of the Parachute Creek Member. 


\section{EVACUATION CREEK MEMBER}

The Evacuation Creek Member is named for exposures along Evacuation Creek in Uintah County, Utah, but the type locality was actually measured 4 miles northeast of Evacuation Creek along the canyon of the White River in sec. 27, T. 9 S., R. 25 E., Uintah County (Bradley, 1931, p. 14-15). At the type locality the member is about 530 feet thick and consists chiefly of platy and chippy marlstone, which is lean in organic matter, and scattered beds of rich oil shale and a few thin beds of altered tuff (Bradley, 1931, pl. 8).

In the Piceance Creek basin at the type locality of the Parachute Creek Member, Bradley (1931, pl. 7) placed the lower boundary of an incompletely measured section of the Evacuation Creek Member at the base of a massive sandstone, about 20 feet thick, which is about 350 feet above the Mahogany ledge. On the north side of the basin in the vicinity of Piceance Creek, Bradley (1931, p. 14), noting the increased sandy character of the member, found a sequence of sandy marlstone and alternating beds of brown sandstone and marlstone more than 840 feet thick that he assigned to the Evacuation Creek. These rocks are overlain by 400 feet of "sandy beds" that Bradley provisionally asigned to the Bridger Formation. Donnell (1961, p. 857-858), finding no mappable base for these sandy beds, included them in the Evacuation Creek Member. Donnell (1961, p. 857) placed the base of the member at the first occurrence of intertonguing sandstone or siltstone more than 10 feet thick, which is generally found about 200 to 500 feet above the Mahogany ledge. As thus redefined, the Evacuation Creek Member in the Piceance Creek basin has a total thickness of more than 1,500 feet and includes a transitional sequence of sandstones and marlstones which grade upward into predominantly massive brown medium- to coarse-grained sandstone and some thin beds of marlstone and siltstone. Most workers have subsequently followed Donnell's redefinition of the member in the Piceance Creek basin.

\section{UINTA FORMATION}

A review of early, somewhat confusing, applications of the name Uinta to rock units in the Uinta Basin is presented by Wood (1934, p. 242-244), who concluded that the first use of Uinta should be credited to Comstock (1875). The Uinta Formation of the eastern Uinta Basin, as used by most authors, is composed of brown sandstone and gray siltstone and marlstone and overlies the Green River Formation (Abbott, 1957; Cashion, 1967; Douglass, 1914; Osborn, 1929; Riggs, 1912). A few hundred feet of strata in the lower part of the sequence, assigned to the Uinta Formation in this report, was placed in the Bridger Formation by a few early workers, but Bridger has not been used for these rocks in recent reports describing the Uinta Basin. The Uinta Formation is divided into parts A, B, and C from lower to upper, based on vertebrate fossil studies. This usage evolved from 


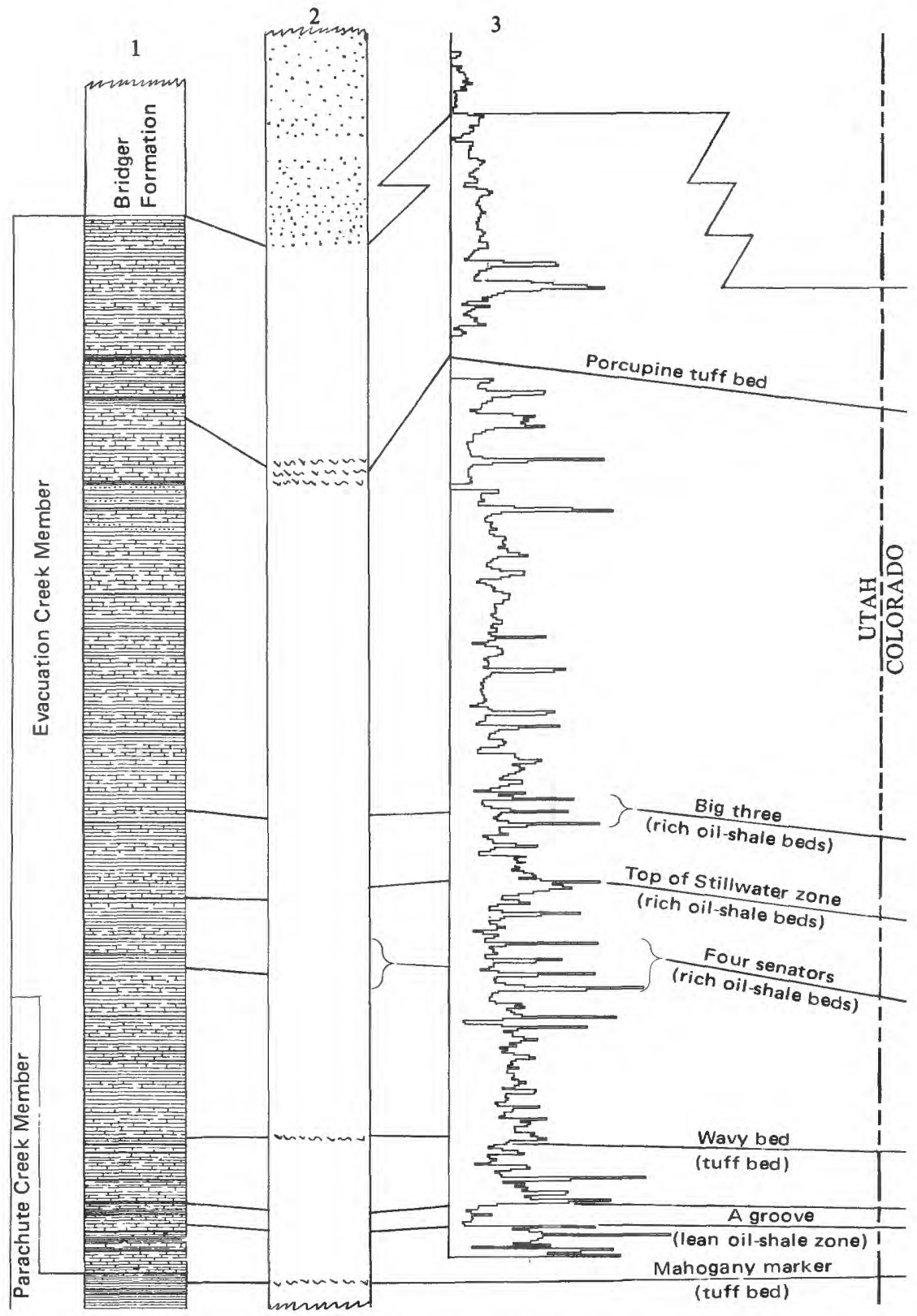

Figure 2. - Upper part of the Green River Formation between the type localities of the keyed to locations shown in figure 1 and described in table 1 . Stratigraphic datum is 


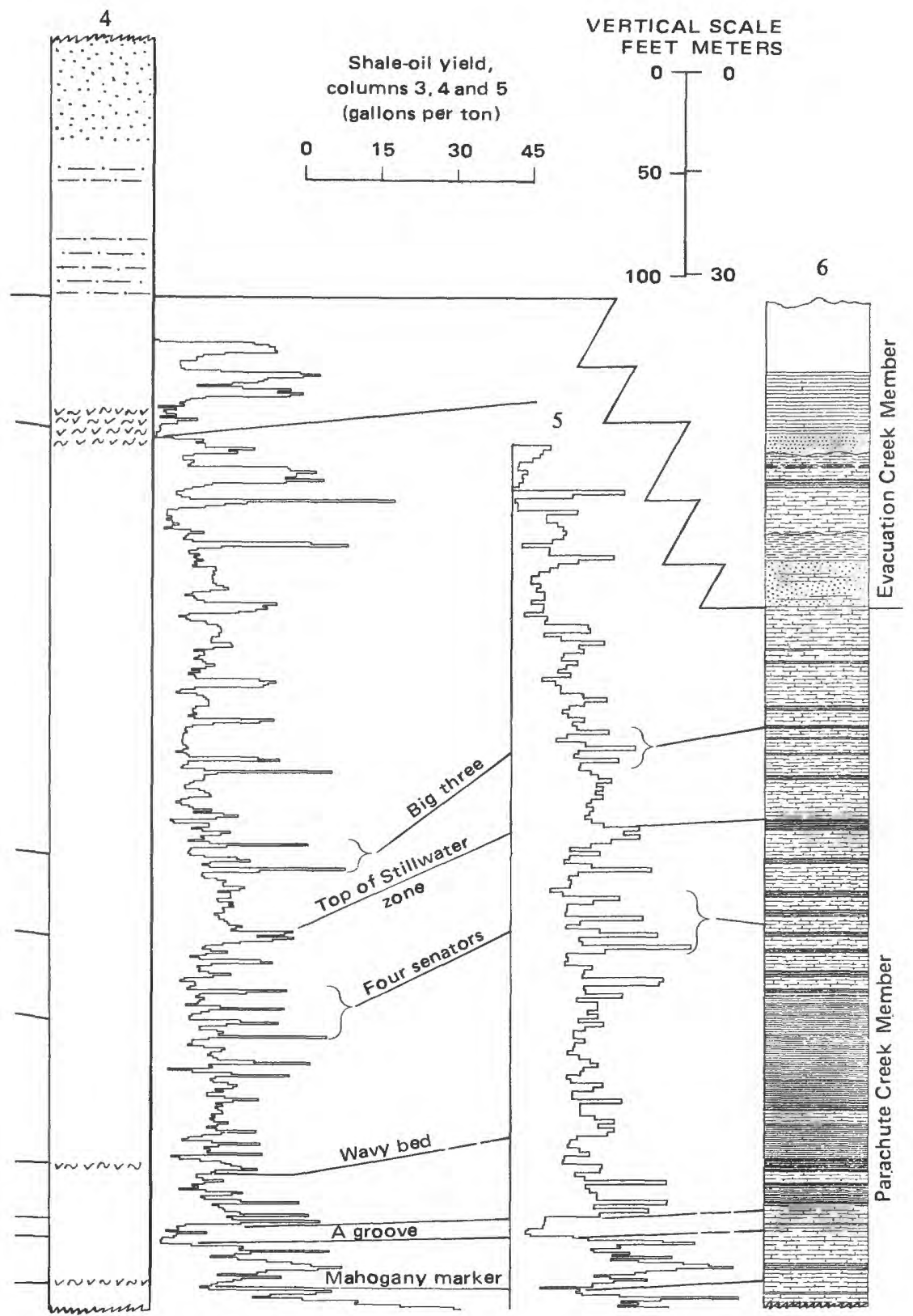

Evacuation Creek and Parachute Creek Members of Bradley (1931). Column numbers are is the Mahogany marker. Explanation of lithologic symbols is on the following page. 


\section{EXPLANATION FOR LITHOLOGIC SYMBOLS IN FIGURE 2}

\section{COLUMNS 1 AND 6}

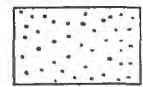

Sandstone

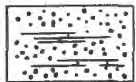

Limy sandstone

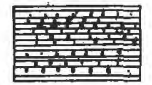

Sandy marlstone

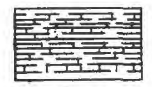

Marlstone

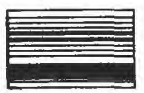

Oil shale

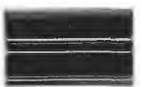

Laminated marlstone

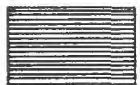

Carbonaceous shale

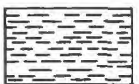

Carbonaceous claystone
CDLUMNS 2 AND 4

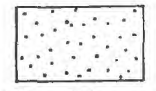

Sandstone

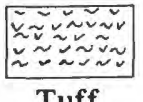

Tuff

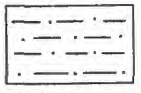

Siltstone

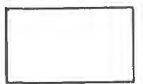

Marlstone and oil shale

Figure 2.- Continued.

the division made by Peterson (Osborn, 1895, p. 72-74), in which the rocks above the Green River Formation were separated into "horizons" A, B, and C.

The upper boundary of Uinta A, as originally selected, was later changed to a lower stratigraphic position. (Compare Osborn, 1895, p. 75, and Osborn, 1929, fig. 63.) The lower boundary of Uinta A in the easternmost Uinta Basin is placed at the top of the Green River Formation as designated by Bradley (1931, pl. 12A). As thus defined, Uinta A is approximately 740 feet thick near the confluence of Evacuation Creek and White River and, according to Osborn $(1929$, p. 92$)$, is unfossiliferous. Uinta A interfingers with the upper part of the Green River Formation and pinches out westward in the area between Evacuation Creek and Willow Creek.

Uinta $A$ is chiefly very fine-grained to medium-grained sandstones interbedded with thin marlstone in the lower part and siltstones in the upper 
TABLE 1. - Locations of core holes and sections shown in figure 1

\begin{tabular}{|c|c|c|}
\hline Location no. & Description & County and State \\
\hline 1 & $\begin{array}{l}\text { Surface section of type Evacuation Creek } \\
\text { Member of Bradley (1931, pl. 8), in sec. } \\
\text { 27, T. } 9 \text { S., R. } 25 \text { E. }\end{array}$ & Uintah County, Utah \\
\hline 2 & $\begin{array}{l}\text { Surface section measured by W. B. Cashion } \\
\text { and } R \text {. W. Blair, Jr., near mouth of } \\
\text { Evacuation Creek. }\end{array}$ & Do. \\
\hline 3 & $\begin{array}{l}\text { Shell Oil Company core hole } 1 \text {, in sec. } 2, \mathrm{~T} \text {. } \\
10 \text { S., R. } 24 \text { E. }\end{array}$ & Do. \\
\hline 4 & $\begin{array}{l}\text { Composite of U.S. Bureau of Land Manage- } \\
\text { ment, Triangulation Station Shale core } \\
\text { hole } 1 \text {, in sec. } 13, \text { T. } 7 \text { S., R. } 97 \text { W., and } \\
\text { core hole 2, in sec. } 24, \text { T. } 7 \text { S., R. } 97 \text { W. }\end{array}$ & Garfield County, Colo. \\
\hline 5 & $\begin{array}{l}\text { Union Oil Company, Jann core hole, in sec. } \\
\text { 33, T. } 5 \text { S., R. } 96 \text { W. }\end{array}$ & Do. \\
\hline 6 & $\begin{array}{l}\text { Surface section of type Parachute Creek } \\
\text { Member measured by Bradley (1931, pl. } \\
\text { 7) on Parachute Creek in Tps. } 5 \text { and } 6 \text { S., } \\
\text { R. } 96 \text { W. }\end{array}$ & Do. \\
\hline
\end{tabular}

part. Bedding is thin to massive, and many thin sequences are crossbedded. Sandstones in the lowermost 250 feet are contorted by differential compaction or plastic flowage prior to lithification. Uinta A weathers to yellowbrown cliffs and ledges with some steep gray and yellow-brown slopes. The appearance and lithology of Uinta A are similar to those of rocks that have been called the Evacuation Creek Member in the Piceance Creek basin.

\section{CORREZATIONS}

Stratigraphic and lithologic equivalency of the upper part of type Parachute Creek Member and the lower part of type Evacuation Creek Member is shown by Curry (1964). The correlation between thin rich oilshale beds in the Uinta Basin and thicker richer beds in the Piceance Creek basin is not easily perceived in outcrops, due to the differences in weathering characteristics, but is easily recognized when comparing oil-yield histograms or geophysical logs. Several rich oil-shale zones and thin tuff beds are identifiable over large areas and have been given informal names (fig. 2).

Curry $(1964$, p. 171$)$ also pointed out that the lower part of the Uinta Formation is equivalent to a part of the Evacuation Creek Member, as it is commonly mapped in the Piceance Creek basin. The lithology of the Evacuation Creek Member of the Piceance Creek basin is essentially the same as that of the lower part of the Uinta Formation of the Uinta Basin. During some period of geologic history, both units were probably one laterally continuous body of interfingering fluvial and lacustrine sediments containing clastic material that was derived from a northerly or northeasterly source. 


\section{NOMENCLATURE CHANGES}

On the basis of the stratigraphic relations described above and shown in figure 2, the following changes are made in the nomenclature of the Green River, Uinta, and Bridger Formations of the Piceance Creek and Uinta Basins (fig. 3):

1. The name Evacuation Creek Member is abandoned.

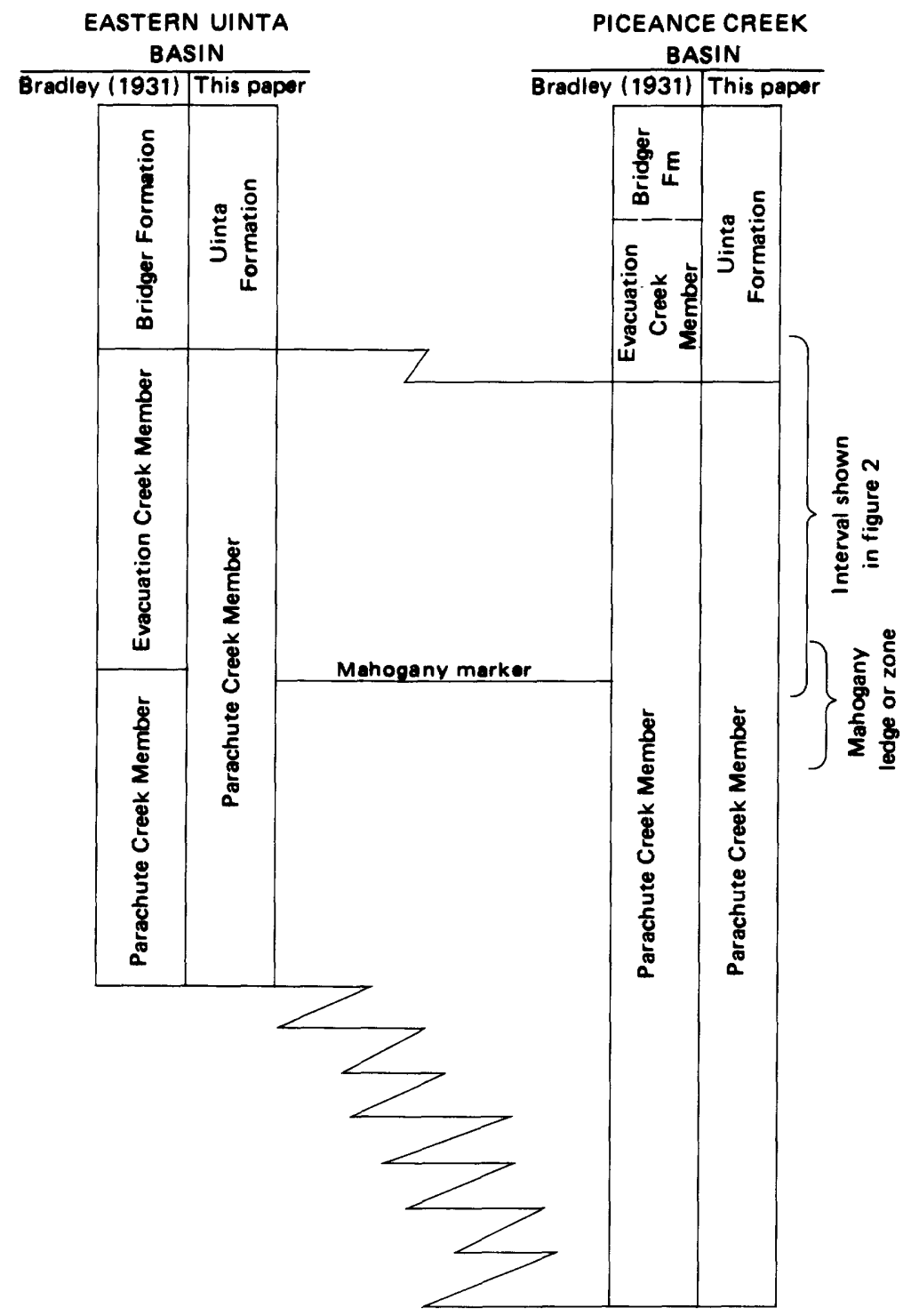

FIGURE 3. - Stratigraphic nomenclature of Bradley (1931) and of this paper. 
2. The upper boundary of the Parachute Creek Member is placed at the base of the Uinta Formation and thus the Parachute Creek Member includes all rocks previously assigned to the Evacuation Creek Member in the Uinta Basin.

3. The name Uinta Formation is extended to the Piceance Creek basin for the stratigraphic sequence previously assigned to the Evacuation Creek Member by Donnell and other recent workers.

4. The name Bridger Formation is restricted from the Uinta and Piceance Creek basins.

\section{REFERENCES}

Abbott, Ward, 1957, Tertiary of the Uinta Basin, in Intermountain Assoc. Petroleum Geologists Guidebook, 8th Ann. Field Conf., Geology of the Uinta Basin: p. 102-109.

Bradley, W. H., 1931, Origin and microfossils of the oil shale of the Green River Formation of Colorado and Utah: U.S. Geol. Survey Prof. Paper 168, 58 p.

Cashion, W. B., 1967, Geology and fuel resources of the Green River Formation, southeastern Uinta Basin, Utah and Colorado: U.S. Geol. Survey Prof. Paper 548, 48 p.

Comstock, T. B., 1875, Geological report, in Jones, W. A., Report upon the reconnaissance of northwestern Wyoming, including Yellowstone National Park, for 1873 [2d ed.]:U.S. Cong., 43d, 1st sess., House Representatives Executive Doc. 285, p. 85-292 (1st ed., p. 85-184, 1874).

Curry, H. D., 1964, Oil-content correlations of Green River oil shales, Uinta and Piceance Creek Basins, in Intermountain Assoc. Petroleum Geologists Guidebook, 13th Ann. Field Conf., Uinta Basin, 1964: p. 169-171.

Donnell, J. R., 1961, Tertiary geology and oil-shale resources of the Piceance Creek basin between the Colorado and White Rivers, northwestern Colorado: U.S. Geol. Survey Bull. 1082-L, p. 835-891.

Douglass, Earl, 1914, Geology of the Uinta Formation: Geol. Soc. America Bull., v. 25, p. 417-420.

Osborn, H. F., 1895, Fossil mammals of the Uinta beds: Am. Mus. Nat. History, Bull., v. 7, p. 71-106.

1929, The titanotheres of ancient Wyoming, Dakota and Nebraska: U.S. Geol. Survey Mon. 55 , v. 1, p. 1-701.

Riggs, E. S., 1912, New or little known titanotheres from the lower Uintah formations: Field Mus. of Nat. History Pub. 159, geol. ser., v. 4, no. 2, p. 17-41.

Wood, H. E., 1934, Revision of the Hyrachyidae: Am. Mus. Nat. History Bull., v. 67, p. 181-295. 





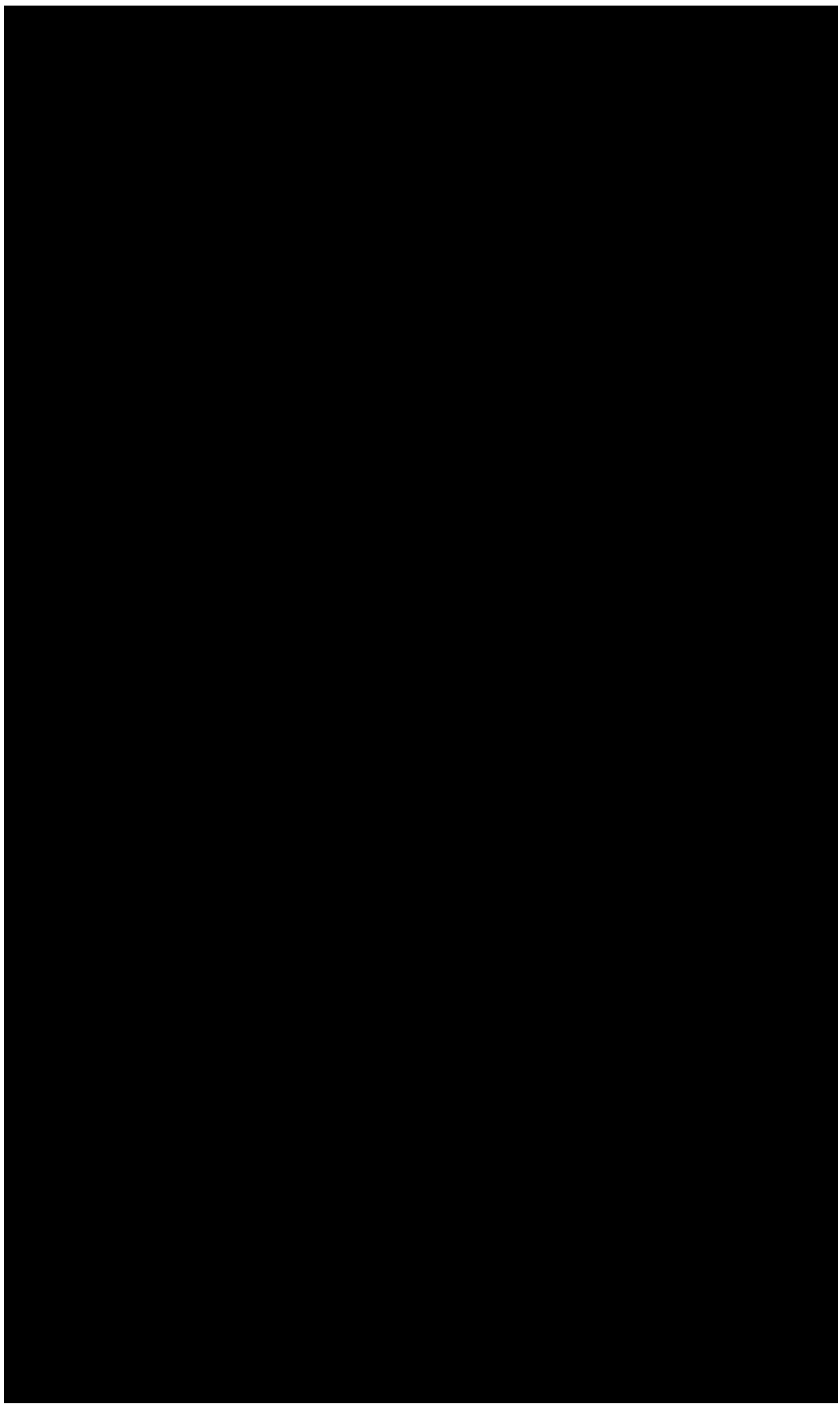




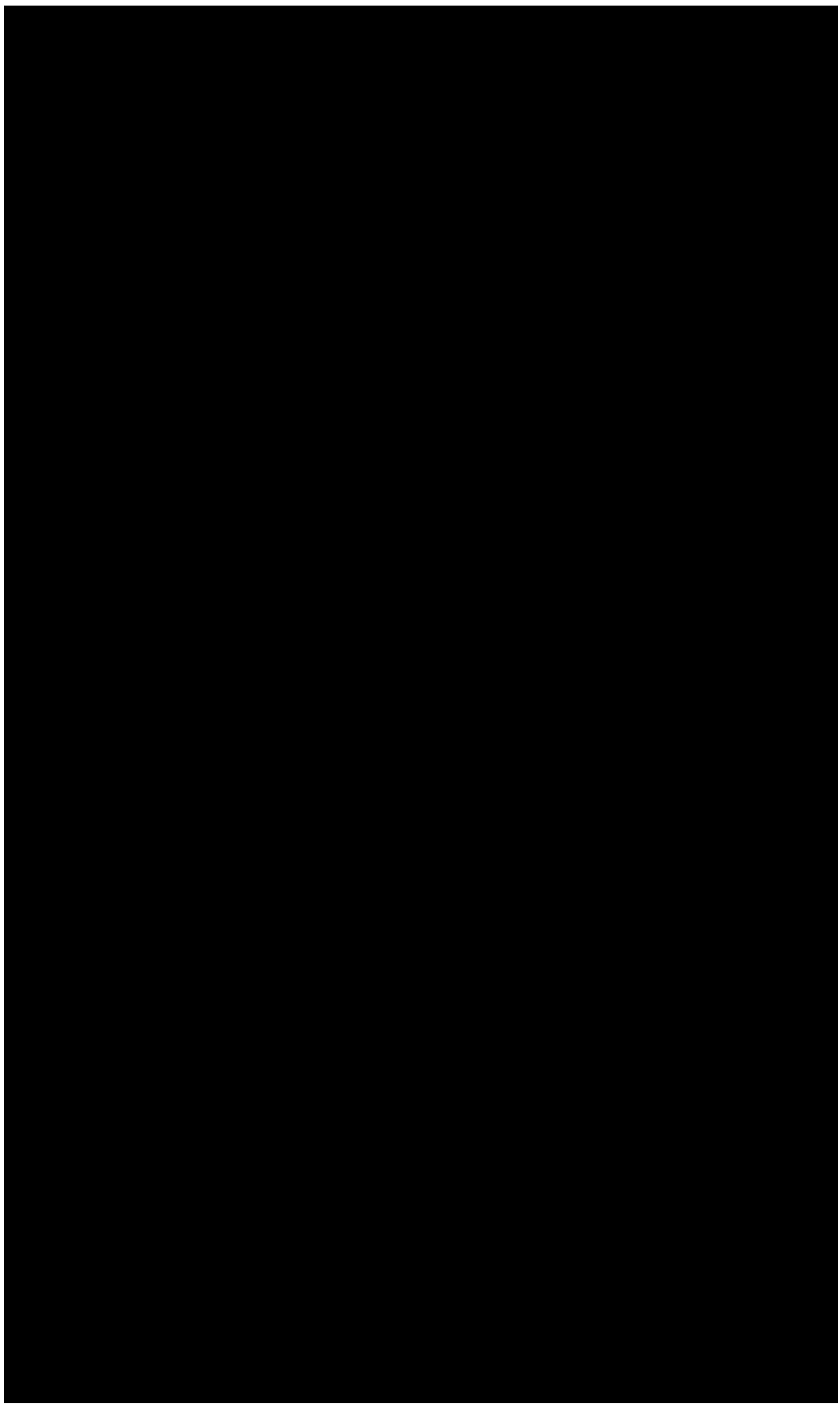

